\title{
Seasonal cycle of benthic denitrification and DNRA in the aphotic coastal zone, northern Baltic Sea
}

\author{
D. Hellemann ${ }^{1,2, *}$, P. Tallberg ${ }^{1,2}$, S. L. Aalto ${ }^{3,4}$, M. Bartoli ${ }^{5}$, S. Hietanen ${ }^{1,2}$ \\ ${ }^{1}$ Ecosystems and Environment Research Program, Faculty of Biological and Environmental Sciences, University of Helsinki, \\ 00014 Helsinki, Finland \\ ${ }^{2}$ Tvärminne Zoological Station, University of Helsinki, 10900 Hanko, Finland \\ ${ }^{3}$ Department of Biological and Environmental Science, University of Jyväskylä, 40014 Jyväskylä, Finland \\ ${ }^{4}$ Department of Environmental and Biological Sciences, University of Eastern Finland, 70211 Kuopio, Finland \\ ${ }^{5}$ Department of Chemistry, Life Sciences and Environmental Sustainability, University of Parma, 43124 Parma, Italy
}

\begin{abstract}
Current knowledge on the seasonality of benthic nitrate reduction pathways in the aphotic, density stratified coastal zone of the Baltic Sea is largely based on data from muddy sediments, neglecting the potential contribution of sandy sediments. To gain a more comprehensive understanding of seasonality in this part of the Baltic Sea coast, we measured rates of benthic denitrification, anammox and dissimilatory nitrate reduction to ammonium (DNRA) monthly in the ice-free period of 2016 in both sandy and muddy aphotic sediments, northwestern Gulf of Finland. No anammox was observed. The seasonal cycle of denitrification in both sediment types was related to the hydrography-driven development of bottom water temperature. The seasonal cycle of DNRA was less clear and likely connected to a combination of bottom water temperature, carbon to nitrogen ratio, and substrate competition with denitrification. Denitrification and DNRA rates were $50-80$ and $20 \%$ lower in the sandy than in the muddy sediment. The share of DNRA in total nitrate reduction, however, was higher in the sandy than in the muddy sediment, being (by $\sim 50 \%$ ) the highest DNRA share in sandy sediments so far measured. Our data add to the small pool of published studies showing significant DNRA in both cold and/or sandy sediments and suggest that DNRA is currently underestimated in the Baltic coastal nitrogen filter. Our results furthermore emphasize that the various environmental conditions of a coastal habitat (light regime, hydrography, and geomorphology) affect biogeochemical element cycling and thus need to be considered in data interpretation.
\end{abstract}

KEY WORDS: Nitrate reduction - Sandy sediment - Coastal filter · Benthic-pelagic coupling · Water column density stratification · Organic matter · Geomorphology · Northern Gulf of Finland

\section{INTRODUCTION}

Coastal ecosystems commonly exhibit a tight benthic-pelagic coupling due to their shallow water depth (Middelburg \& Soetaert 2004), which connects the elemental cycles of sediment and water column, linking benthic organic matter mineralization to pelagic organic matter production. Geomorphological and hydrographic features of the coastal habitat shape this coupling by affecting water and particle residence time, water column mixing, and eventually the avail-

*Corresponding author: dana.hellemann@helsinki.fi ability of organic matter in the benthic system. Heterotrophic denitrification, the stepwise reduction of nitrate $\left(\mathrm{NO}_{3}{ }^{-}\right)$to di-nitrogen gas $\left(\mathrm{N}_{2}\right)$ during oxidation of organic carbon, not only contributes to organic matter mineralization, but is the key process of removing bioavailable nitrogen $(\mathrm{N})$ in coastal systems, often favored over autotrophic anaerobic ammonium oxidation (anammox; Dalsgaard et al. 2005).

In the Baltic Sea, the seasonal cycle of benthic denitrification can contrast strongly between the shallow, photic, mixed and the deeper, aphotic, stratified restricted. Authors and original publication must be credited. 
coastal zone. The threshold between the zones is around $10 \mathrm{~m}$ water depth, which is where the average mixed surface layer ends (Leppäranta \& Myrberg 2009) and where light availability starts to limit benthic primary production (Secchi depth $<10 \mathrm{~m}$ in 2011-2016; HELCOM 2018a). In the photic, mixed zone, benthic denitrification rates often peak in early spring, when $\mathrm{NO}_{3}{ }^{-}$concentrations are high, bottom water temperatures quickly increase, and microbial competition with microphytobenthos for $\mathrm{NO}_{3}{ }^{-}$and ammonium $\left(\mathrm{NH}_{4}{ }^{+}\right)$is still low (Sørensen 1984, Jørgensen \& Sørensen 1985, Nielsen et al. 1995, Rysgaard et al. 1995). In contrast, in the deeper, aphotic, stratified zone, denitrification rates are often limited in spring and first peak in early autumn (Hietanen \& Kuparinen 2008, Jäntti et al. 2011, Bonaglia et al. 2014, Bartl et al. 2019). This limitation has been associated with seasonally low availability of labile organic carbon (Hietanen \& Kuparinen 2008, Jäntti et al. 2011, Bartl et al. 2019); as the main share of landderived particulate and dissolved organic matter (POM, DOM) often remains in shallower areas, deeper areas are largely dependent on the supply of POM from pelagic autochthonous primary production, which starts in spring and, contrary to DOM, can sink across stratified water layers (Bartl et al. 2019). Peak denitrification rates in early autumn seem to result from high availability of $\mathrm{N}$ and labile organic carbon from mineralized phytoplankton, and the annually highest bottom water temperatures at the breakdown of water column stratification (Hietanen \& Kuparinen 2008, Jäntti et al. 2011, Bonaglia et al. 2014). In the shallow coastal zone, the seasonal pattern of denitrification has been observed both in sandy and 'muddy' sediments, whereas observations from the deeper areas are based only on cohesive, fine-grained muddy sediments. Hence, although roughly $30 \%$ of the Baltic coastal sediments consist of sand and are located to a large part in the aphotic stratified zone (Al-Hamdani \& Reker 2007), little is known about the seasonal pattern of denitrification there.

Dissimilatory nitrate reduction to ammonium (DNRA) is another $\mathrm{NO}_{3}{ }^{-}$reduction process that has been shown to be important in coastal sediments (Giblin et al. 2013), but has not been quantified in Baltic coastal sandy sediments. When DNRA is heterotrophic, it competes with denitrification for organic carbon as an electron donor (Tiedje 1988), which can affect the seasonal cycle of both processes as well as our understanding of the 'coastal $\mathrm{N}$ filter' (i.e. all $\mathrm{N}$ retention and removal processes within the coastal zone that mitigate the export of $\mathrm{N}$ to open waters; Asmala et al. 2017). While denitrification removes bioavailable $\mathrm{N}$ from the aquatic system and thereby contributes to mitigating eutrophication, DNRA retains bioavailable $\mathrm{N}$ in the system and thereby can foster eutrophication, affecting the functioning of the coastal filter (Jäntti \& Hietanen 2012). So far, DNRA has often been suggested to be of minor importance in cold environments (Jäntti et al. 2011, Crowe et al. 2012, Giblin et al. 2013) and insignificant in sandy sediments where the common environmental conditions, e.g. low concentrations of the electron donors organic carbon and hydrogen sulfide $\left(\mathrm{H}_{2} \mathrm{~S}\right)$, should theoretically disfavor DNRA against denitrification (Tiedje 1988, Kraft et al. 2014). Recent studies, however, show the substantial role of DNRA in total $\mathrm{NO}_{3}{ }^{-}$reduction both in cold (Bonaglia et al. 2017) and sandy (Behrendt et al. 2013, Erler et al. 2014, Marchant et al. 2014) sediments, suggesting that DNRA could also play an important role in the coastal sandy sediments of the cold Baltic Sea.

The lack of knowledge on seasonality and controls of these $\mathrm{N}$ transformations in a substantial part of the Baltic coastal N filter is of concern, as the Baltic coastal zone receives annually $\sim 680 \mathrm{kt}$ of land-derived waterborne total N (average 1994-2014; HELCOM 2015, 2018b) that have already led to eutrophication-induced ecosystem deterioration (Conley et al. 2011). Hence, we quantified benthic denitrification, anammox, and DNRA monthly in the ice-free period of 2016 in both muddy and sandy sediments at the aphotic, stratified coastal zone of southern Finland. We hypothesize that $\mathrm{N}$ removal by denitrification and anammox, if present, follows a similar seasonal pattern in both sediment types, driven by a similar seasonal hydrography due to similar water depths. Furthermore, DNRA may contribute to total $\mathrm{NO}_{3}{ }^{-}$reduction in both sediment types, as recent studies suggest its potential occurrence both in sandy and cold sediments.

\section{MATERIALS AND METHODS}

\subsection{Study area and sampling}

Both sampling sites were located in the outer archipelago of the Hanko peninsula, northwestern Gulf of Finland (Fig. 1). This brackish coastal area is seasonally density-stratified (spring to autumn) and ice covered (winter to spring); the spring bloom generally occurs between April and May (Niemi 1973). The sandy site $\left(24 \mathrm{~m} ; 59^{\circ} 48.56^{\prime} \mathrm{N}, 23^{\circ} 05.38^{\prime} \mathrm{E}\right)$ was located in nearly open waters with only a few sparsely vegetated islands in its immediate vicinity, while the muddy site (33 $\left.\mathrm{m} ; 59^{\circ} 51.21^{\prime} \mathrm{N}, 23^{\circ} 15.56^{\prime} \mathrm{E}\right)$ was located within the accumulation basin Storfjärden and surrounded 
by several vegetated islands (Fig. 1). The sediment surface at both sites was aphotic (LI-1400 data logger, Li-COR).

Samples were collected monthly from April-November 2016 onboard the RV 'Saduria' (Tvärminne Zoological Station; Table1). Hydrographicparameters were measured with a conductivitytemperature-depth probe (Mini-CTD, Valeport; Citadel CTD-NV-1, Teledyne RD Instruments), before sediment samples were collected with a GEMAX twin corer (core i.d. $9 \mathrm{~cm}$, length $80 \mathrm{~cm}$; mud) and a HAPS bottom corer with vibration unit (core i.d. $14 \mathrm{~cm}$, length $30 \mathrm{~cm}$, vibration time $10-15 \mathrm{~s}$; sand). From the first sediment core, water samples for the analysis of near-bottom concentrations of dissolved oxygen and $\mathrm{N}$-nutrient $\left(\mathrm{NO}_{2}{ }^{-}+\mathrm{NO}_{3}{ }^{-}\right.$and $\left.\mathrm{NH}_{4}{ }^{+}\right)$ were taken from $\sim 5 \mathrm{~cm}$ above the sediment surface. Subsequently, the top surface sediment $(0-1 \mathrm{~cm})$ was sampled for the analysis of porosity and loss on ignition (LOI). At the sandy

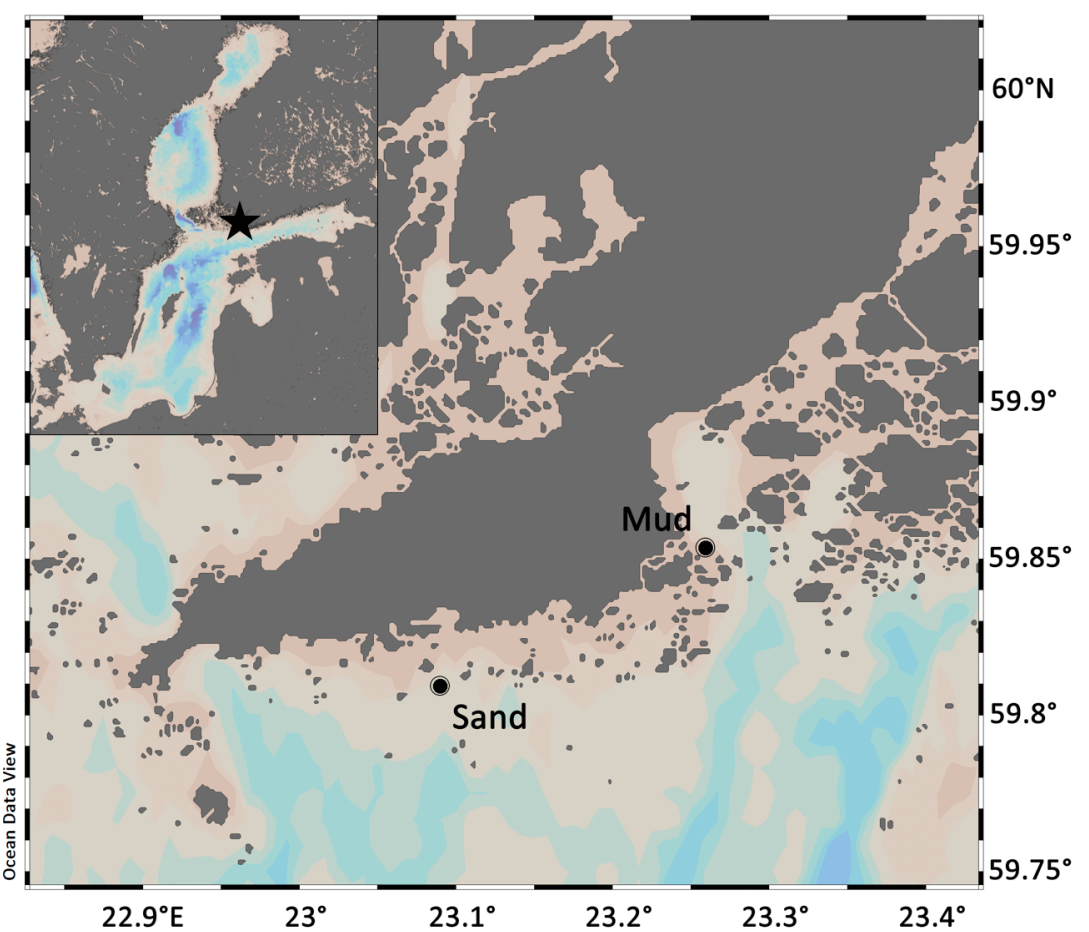

Fig. 1. Sandy and muddy study sites in the outer archipelago of the Hanko peninsula at the southern coast of Finland, northern Baltic Sea. Drawn using Ocean Data View (Schlitzer 2015) site, additional surface sediment samples were taken for the analysis of permeability $(\sim 11$ of pooled surface sediments from the homogeneous top $0-2 \mathrm{~cm})$ and grain size distribution $(0-1,1-2 \mathrm{~cm})$. From the following cores, subsamples for the analysis of oxygen penetration depth (OPD, $\mathrm{n}=3$ site $\left.^{-1}\right), \mathrm{N}_{2}$ production, and DNRA ( $\mathrm{n}=20$ site $^{-1}$ ) were collected in acrylic cores (i.d. $2.3 \mathrm{~cm}$, length $15 \mathrm{~cm}$ ), which were pushed gently into the sediment to fill $\sim 30 \%$

Table 1. Sampling and sediment parameters of the sandy $(24 \mathrm{~m})$ and muddy $(33 \mathrm{~m})$ sites. BW-S: bottom water salinity; $\phi$ : porosity $(0-1 \mathrm{~cm}$ depth); $K_{\mathrm{m}}$ : sediment permeability $(0-2 \mathrm{~cm}$ depth); LOI: loss on ignition $(0-1 \mathrm{~cm}$ depth); OPD: oxygen penetration depth; DOU: diffusive oxygen uptake; surface ammonium $\left(\mathrm{NH}_{4}{ }^{+}\right)$pool: $0-1 \mathrm{~cm}$ vertical integration; deep $\mathrm{NH}_{4}{ }^{+}$pool: $1-6 \mathrm{~cm}$ vertical integration; $\mathrm{NH}_{4}{ }^{+}$fluxes calculated from pore-water profiles. LOI, OPD, and DOU are averages $( \pm \mathrm{SD})$, with number of replicates in brackets. In November, gas ebullition destroyed samples at the muddy site. na: not analyzed

\begin{tabular}{|c|c|c|c|c|c|c|c|c|c|c|}
\hline \multirow{2}{*}{ Sediment } & \multicolumn{2}{|c|}{ Sampling } & \multicolumn{8}{|c|}{-Sediment } \\
\hline & Month & BW-S & $\phi$ & $\begin{array}{c}K_{\mathrm{m}} \\
\left(10^{-12} \mathrm{~m}^{2}\right)\end{array}$ & $\begin{array}{c}\text { LOI } \\
\text { (weight \%) }\end{array}$ & $\begin{array}{l}\text { OPD } \\
(\mathrm{mm})\end{array}$ & $\begin{array}{c}\text { DOU } \\
\left(\mathrm{mmol} \mathrm{m}^{-2} \mathrm{~d}^{-1}\right)\end{array}$ & $\begin{array}{l}\text { Surface } \mathrm{NH}_{4}^{+} \text {pool } \\
\quad\left(\mathrm{mmol} \mathrm{m}^{-2}\right)\end{array}$ & $\begin{array}{c}\text { Deep } \mathrm{NH}_{4}^{+} \text {pool } \\
\left(\mathrm{mmol} \mathrm{m}^{-2}\right)\end{array}$ & $\begin{array}{c}\mathrm{NH}_{4}{ }^{+} \text {flux } \\
\left(\mathrm{mmol} \mathrm{m}^{-2} \mathrm{~d}^{-1}\right)\end{array}$ \\
\hline \multirow[t]{8}{*}{ Sand } & Apr & 5.6 & 0.47 & 2.2 & $1.1 \pm 0.1(3)$ & $10.0 \pm 0.9(6)$ & $0.89 \pm 0.30(6)$ & 0.07 & 1.79 & 0.02 \\
\hline & May & 5.5 & 0.46 & 2.3 & $1.0 \pm 0.2$ & $7.0 \pm 0.5(7)$ & $1.37 \pm 0.26(7)$ & 0.17 & 2.85 & 0.06 \\
\hline & June & 5.5 & 0.46 & 2.2 & $0.8 \pm 0.1$ & $3.5 \pm 0.6(6)$ & $1.44 \pm 0.21$ & 0.04 & 1.79 & 0.01 \\
\hline & July & 6.3 & 0.47 & na & $0.9 \pm 0.1$ & $2.1 \pm 0.1$ & $1.64 \pm 0.12$ & 0.15 & 2.21 & 0.05 \\
\hline & Aug & 6.1 & 0.48 & 1.9 & $1.2 \pm 0.1$ & $2.6 \pm 0.2(6)$ & $1.59 \pm 0.41(6)$ & 0.05 & 1.71 & 0.02 \\
\hline & Sept & 6.0 & 0.48 & 1.6 & $1.0 \pm 0.1$ & $3.0 \pm 0.2(8)$ & $1.44 \pm 0.37(8)$ & 0.25 & 2.53 & 0.11 \\
\hline & Oct & 5.9 & 0.43 & 1.6 & $1.1 \pm 0.0$ & $3.2 \pm 0.6(8)$ & $2.26 \pm 0.51$ & 0.37 & 3.11 & 0.13 \\
\hline & Nov & 5.5 & 0.45 & 1.9 & $1.1 \pm 0.1$ & $4.6 \pm 0.8(8)$ & $1.36 \pm 0.25$ & 0.29 & 2.42 & 0.09 \\
\hline \multirow[t]{8}{*}{ Mud } & Apr & 5.6 & 0.95 & na & $13.9 \pm 0.1$ & $6.3 \pm 1.5(6)$ & $7.84 \pm 2.60(6)$ & 0.24 & 5.00 & 0.35 \\
\hline & May & 5.5 & 0.95 & na & $13.7 \pm 0.2$ & $4.6 \pm 0.6$ & $7.37 \pm 2.10(6)$ & 0.27 & 6.24 & 0.44 \\
\hline & June & 6.8 & 0.97 & na & $15.7 \pm 0.2$ & $2.9 \pm 0.1$ & $8.18 \pm 1.18$ & 0.12 & 9.41 & 0.17 \\
\hline & July & 6.6 & 0.96 & na & $14.3 \pm 0.1$ & $2.4 \pm 0.4$ & $9.92 \pm 3.36$ & 0.13 & 12.93 & 0.19 \\
\hline & Aug & 6.3 & 0.96 & na & $15.8 \pm 0.1$ & $3.4 \pm 0.7$ & $7.33 \pm 1.76$ & 0.05 & 4.56 & 0.08 \\
\hline & Sept & 6.1 & 0.96 & na & $15.0 \pm 1.5$ & $3.1 \pm 0.1$ & $6.87 \pm 3.16$ & 0.11 & 8.41 & 0.11 \\
\hline & Oct & 6.0 & 0.95 & na & $15.5 \pm 5.0$ & $1.8 \pm 0.3$ & $4.00 \pm 2.05$ & 0.07 & 8.14 & 0.11 \\
\hline & Nov & 5.4 & 0.97 & na & na & na & na & na & na & na \\
\hline
\end{tabular}


(mud) to $\sim 50 \%$ (sand) of each core volume and subsequently closed under water without headspace; a larger volume was taken from the sandy sediment to take a potentially deeper OPD into account. Intact sediment cores $\left(\mathrm{n}=1 \mathrm{site}^{-1}\right.$; sand: i.d. $8.4 \mathrm{~cm}$, mud: i.d. $9.0 \mathrm{~cm}$ ) were taken for the analysis of pore-water $\mathrm{NH}_{4}{ }^{+}$concentrations and subsampled with Rhizons ${ }^{\mathrm{TM}}$ (membrane length $5 \mathrm{~cm}$, i.d. $2.5 \mathrm{~mm}$, mean pore size $0.15 \mu \mathrm{m}$; Rhizosphere Research Products; SeebergElverfeldt et al. 2005), inserted horizontally into the sediment through pre-drilled holes $(1 \mathrm{~cm}$ resolution over 0-6 cm depth). Pore-water samples were stored frozen $\left(-20^{\circ} \mathrm{C}\right)$ until analysis; all other samples were stored dark and cold until processing within 1-2 h (N processes, OPD; bottom water in situ temperature), maximal $6 \mathrm{~h}$ (dissolved oxygen, nutrients; $4^{\circ} \mathrm{C}$ ) and 1-2 d (sediment characteristics; $4^{\circ} \mathrm{C}$ ) of sampling.

\subsection{Bottom current measurements}

In winter (15 Dec 2015-14 Jan 2016) and spring (5 Apr 2016-7 Jun 2016) of the sampling year, a recording current meter (Shallow Water SeaGuard with ZPulse $^{\mathrm{TM}}$ multi-frequency Doppler current sensor; tilt compensation, current velocity $\pm 0.15 \mathrm{~cm} \mathrm{~s}^{-1}$, current direction $\pm 2^{\circ}$; Aanderaa Data Instruments) equipped with a turbidity sensor (Aanderaa Data Instruments) was deployed close to the sandy site $\left(59^{\circ} 48.52^{\prime} \mathrm{N}\right.$, $\left.23^{\circ} 05.15^{\prime} \mathrm{E}\right)$ at $\sim 1 \mathrm{~m}$ above the sea bottom. Current velocity was recorded in intervals of $30 \mathrm{~s}$ (150 acoustic pulses, burst mood) for 15 min every hour, subsequently averaged for $1 \mathrm{~min}$, and sorted by direction. The recorded periods included conditions of seasonal high water turbulence and the onset of water column density stratification.

\subsection{Characteristics of the benthic environment}

Dissolved oxygen concentrations were measured by Winkler titration, N-nutrient concentrations were measured manually $\left(\mathrm{NH}_{4}{ }^{+}\right.$, determination limit: $0.14 \mu \mathrm{M}$ ) and with an auto analyzer (Thermo Scientific Aquakem 250; $\mathrm{NO}_{3}{ }^{-}+\mathrm{NO}_{2}{ }^{-}$, determination limit: $0.20 \mu \mathrm{M})$, according to Grasshoff et al. (1983). Sediment porosity and LOI were determined via weight loss upon drying $\left(105^{\circ} \mathrm{C}\right.$, overnight $)$ and subsequent weight loss upon combustion $\left(550^{\circ} \mathrm{C}\right.$, $4 \mathrm{~h})$, calculations followed Burdige (2006). The grain size distribution of the sandy sediment was analyzed by laser particle size analysis (CILAS 1180 Nass) after freeze-drying, and subsequently, the sand type was classified from pooled $(0-2 \mathrm{~cm})$ results due to vertical homogeneity, according to Wentworth (1922). Sand permeability $\left(K_{\mathrm{m}}\right)$ was analyzed with a permeameter (Humboldt) following the constant head method for laminar flow of water through granular soil, with calculations derived from Darcy's Law as described in Hellemann et al. (2017). At $K_{\mathrm{m}} \geq 2.5 \times 10^{-12} \mathrm{~m}^{2}$, sandy sediment in the Baltic Sea is considered permeable enough to enable advective pore-water flow with significant effects on sediment biogeochemistry (Forster et al. 2003). Additionally, the bottom flow velocity that would be necessary to create high enough pressure gradients via the interaction with site-specific sediment topography (Huettel \& Gust 1992) to theoretically drive pore-water flow in the sand of measured permeability was estimated using Huettel et al. (1996, their Fig. 4) and Bear (1972) (see Text S1 in the Supplement at www.int-res.com/articles/suppl/ m637p015_supp.pdf).

Concentration profiles of pore-water oxygen $(\mathrm{n}=$ 3 core $^{-1}$ ) were measured at in situ temperature using Clark-type microelectrodes (200 $\mu \mathrm{m}$ vertical resolution; OX-100, Unisense), calibrated before profiling at in situ salinity and temperature (2-point calibration: 0 and $100 \%$ oxygen saturation). Subsequently, samples were incubated similarly as the denitrification samples (see Section 2.4), thereafter concentration profiles were repeated to verify stable incubation conditions. From each profile, the OPD in the sediment was determined, with the sediment surface identified from a characteristic break in the profile curve and additional visual estimation. Replicate OPDs were averaged per month ( $\mathrm{n}=$ 3-9), and profiles visibly affected by fauna were discarded (sand: $\sim 20 \%$; mud: $\sim 9 \%$ of all samples). The profiles were also used to calculate rates of diffusive oxygen uptake (DOU) in the sediment according to Fick's first law of diffusion, using an oxygen diffusion coefficient in the sediment after Schulz (2005), calculated from porosity and the diffusion coefficient in water at in situ temperature and salinity (Ramsing \& Gundersen 2012). The calculation of DOU was possible in both sediment types, as the sandy sediment was not permeable enough for advective pore-water flow and hence mass transport functioned by diffusion (see Section 3.1).

Pore-water $\mathrm{NH}_{4}{ }^{+}$concentrations were analyzed manually according to Grasshoff et al. (1983). From the concentration profiles, diffusive $\mathrm{NH}_{4}{ }^{+}$fluxes across the sediment-water interface were calculated according to Fick's first law of diffusion, using a $\mathrm{NH}_{4}{ }^{+}$ diffusion coefficient in the sediment after Schulz 
(2005), calculated from porosity and the diffusion coefficient in water corrected for in situ temperature (Boudreau 1997) and salinity (Van Cappellen \& Wang 1995). $\mathrm{NH}_{4}{ }^{+}$concentrations were also vertically integrated over the surface $(0-1 \mathrm{~cm})$ and the deeper $(1-6 \mathrm{~cm})$ sediment layer to yield total pools of pore-water $\mathrm{NH}_{4}{ }^{+}$, indicating mineralization and accumulation. Potential ammonification rates were estimated following Soana et al. (2015), whereby the calculated DOU rates were divided with theoretical carbon to nitrogen (C:N) ratios of 5 (very labile, $\mathrm{N}$ rich organic matter) and 20 (refractory, N-depleted organic matter), assuming a 1:1 stoichiometry of oxygen and carbon dioxide.

The in situ faunal community was not identified in this study, but nor was it removed from any samples to represent a realistic picture of the studied ecosystem. Hence, all measured parameters include potential contributions from the faunal community.

\subsection{Benthic $\mathbf{N}$ transformation processes}

Denitrification and anammox were measured with the revised isotope pairing technique (rIPT; Risgaard-Petersen et al. 2003). Nitrous oxide production from denitrification was not measured separately, as a pilot study in 2015 showed negligible production in the study area $(\leq 1.3 \%$ of total denitrification, D. Hellemann unpubl. data), similar to other coastal sites in the Baltic Sea (Hellemann et al. 2017, Bartl et al. 2019). Since the sandy sediment was not permeable enough to facilitate advective pore-water flow (see Section 3.1), all sediment samples were incubated with a diffusive setup. The overlying water in the acrylic cores was enriched with isotopically labelled $\mathrm{NO}_{3}^{-}\left(\mathrm{K}^{15} \mathrm{NO}_{3}\right.$ with $98 \%$ ${ }^{15} \mathrm{~N}$; Cambridge Isotope Laboratories) to final concentrations of 40,80 and $120 \mu \mathrm{M}(\mathrm{n}=4$ concentration $^{-1}$, except $120 \mu \mathrm{M}: \mathrm{n}=12$ for time-series measurements; isotope enrichment in the water: 86.0$99.9 \%$ ), and cores were subsequently incubated under gentle water mixing supporting diffusive solute transport only, using magnetic stirring bars connected to the core caps (in situ temperature, darkness, main incubation: $5 \mathrm{~h}$; time-series: 5, 7, and $10 \mathrm{~h}$ ). Incubations were stopped by mixing the sediment carefully with the overlying water and after brief sediment settling, $12 \mathrm{ml}$ subsamples were placed into gastight glass vials (Exetainer, Labco Scientific) filled with $0.5 \mathrm{ml}$ zinc chloride $(100 \%$ $\mathrm{w} / \mathrm{v}$; Merck). The isotopic composition of $\mathrm{N}_{2}$ was analyzed with a continuous flow isotope ratio mass spectrometer (IRMS; IsoPrime 100, Isoprime; standard gas: $\mathrm{N}_{2}$, $>99.999 \%$ purity, AGA) interfaced with a gas pre-concentrator system (TraceGas, Isoprime) and an automated liquid handler (GX-271, Gilson) at the Department of Environmental Sciences, University of Jyväskylä, Finland.

Valid application of IPT and rIPT requires a linear dependency of the produced ${ }^{15} \mathrm{~N}-\mathrm{N}_{2}$ (D15) with increasing ${ }^{15} \mathrm{NO}_{3}{ }^{-}$concentrations, as well as no correlation of the produced ${ }^{14} \mathrm{~N}-\mathrm{N}_{2}$ (D14, calculated according to IPT; Nielsen 1992) with increasing ${ }^{15} \mathrm{NO}_{3}{ }^{-}$ concentrations if denitrification is the sole $\mathrm{N}_{2}$ production process. Hence, a positive correlation of D14 with ${ }^{15} \mathrm{NO}_{3}{ }^{-}$concentrations indicates $\mathrm{N}_{2}$ production from both denitrification and anammox, whose rates can be separated by following Risgaard-Petersen et al. (2003). All dependencies were tested with regression analyses (significance level $\alpha=0.05$; see Fig. S1). No contribution of anammox to total $\mathrm{N}_{2}$ production was indicated at either site, which also excludes potential ${ }^{30} \mathrm{~N}_{2}$ production from DNRA coupled to anammox (Jensen et al. 2011, Song et al. 2016). Hence, denitrification was the sole $\mathrm{N}_{2}$ production process and rates were calculated following Nielsen (1992), with denitrification of $\mathrm{NO}_{3}{ }^{-}$from the bottom water $\left(D_{\mathrm{w}}\right)$ and from nitrification within the sediment $\left(D_{\mathrm{n}}\right)$ calculated from D14 and the ratio of ${ }^{15} \mathrm{NO}_{3}{ }^{-}$to ${ }^{14} \mathrm{NO}_{3}{ }^{-}$in the water phase.

Following the sampling for $\mathrm{N}_{2}$ isotopic composition, $4 \mathrm{ml}$ subsamples for the quantification of DNRA via accumulation of isotopically labeled $\mathrm{NH}_{4}{ }^{+}\left({ }^{15} \mathrm{NH}_{4}{ }^{+}\right)$ were taken from the same cores, filtered through prewashed cellulose acetate glass fiber filters (CA-GF Filtropur S plus $0.2 \mu \mathrm{m}$; Sarstedt) and stored frozen $\left(-20^{\circ} \mathrm{C}\right)$ until analysis. In October, samples were treated with potassium chloride (final concentration: $2 \mathrm{M})$ to identify the share of particle-associated $\mathrm{NH}_{4}{ }^{+}$. The concentration of ${ }^{15} \mathrm{NH}_{4}{ }^{+}$in the incubation samples was determined by conversion to ${ }^{15} \mathrm{~N}-\mathrm{N}_{2}$ with alkaline hypobromite iodine solution (Risgaard-Petersen et al. 1995), for which a sample volume equaling $\sim 40-$ $80 \mathrm{nmol} \mathrm{NH}_{4}{ }^{+}$was diluted with ultrapure water to a final volume of $4 \mathrm{ml}$ in a gastight glass vial (Exetainer, $12 \mathrm{ml}$ volume; Labco Scientific), flushed with helium for $5 \mathrm{~min}$, and mixed with $100 \mu \mathrm{l}$ alkaline hypobromite iodine solution. Vials were shaken overnight at room temperature, and subsequently ${ }^{15} \mathrm{~N}-\mathrm{N}_{2}$ was measured with an IRMS (Isoprime; see above 'rIPT'). Standards of ${ }^{15} \mathrm{NH}_{4}{ }^{+}\left(5,10\right.$, and $15 \mu \mathrm{M}$ of $5 \%{ }^{15} \mathrm{~N}$-atm $\mathrm{NH}_{4} \mathrm{Cl}$, prepared using $98 \%{ }^{15} \mathrm{NH}_{4} \mathrm{Cl}$ [Cambridge Isotope Laboratories] and unlabeled $\mathrm{NH}_{4} \mathrm{Cl}$ [Sigma]) were treated in parallel with samples to measure the conversion efficiency and ${ }^{15} \mathrm{~N}$ recovery. 
Tracer-independent DNRA rates $\left({ }^{14} \mathrm{~N}\right.$-DNRA) were calculated from the measured accumulation of ${ }^{15} \mathrm{NH}_{4}{ }^{+}$ and the ratio of ${ }^{29 / 30} \mathrm{~N}_{2}$ produced during incubation with ${ }^{15} \mathrm{NO}_{3}{ }^{-}$(i.e. during denitrification; RisgaardPetersen et al. 1995, Christensen et al. 2000). This approach is based on the occurrence of DNRA and denitrification in the same sediment layer, reducing $\mathrm{NO}_{3}{ }^{-}$of the same labeling fraction (Christensen et al. 2000), which also allows for calculation of the source of $\mathrm{NO}_{3}{ }^{-}$reduced by DNRA (bottom water: DNRA $_{w}$, nitrification within the sediment: $D_{N R A}$ ) in the same way as for denitrification, using ${ }^{14} \mathrm{~N}$ DNRA and the ratio of ${ }^{15} \mathrm{NO}_{3}{ }^{-}$to ${ }^{14} \mathrm{NO}_{3}{ }^{-}$in the water phase. The ratio of ${ }^{29 / 30} \mathrm{~N}_{2}$ produced during DNRA measurements themselves cannot be used for the calculation of ${ }^{14} \mathrm{~N}-\mathrm{DNRA}$, as that ratio is affected by the analysis of ${ }^{15} \mathrm{NH}_{4}{ }^{+}$content (Risgaard-Petersen et al. 1995). To account for particle-associated $\mathrm{NH}_{4}{ }^{+}$, we applied correction factors of 1.8 (mud) and 1.9 (sand).

\subsection{Statistical analysis}

The correlation of environmental parameters (bottom water temperature, salinity, dissolved oxygen, $\mathrm{NO}_{2}{ }^{-}+\mathrm{NO}_{3}{ }^{-}$, and $\mathrm{NH}_{4}{ }^{+}$, as well as sediment LOI, OPD, DOU, and $\mathrm{NH}_{4}{ }^{+}$pool) with rates of denitrification and DNRA were tested with a non-parametric analysis (Kendall's tau), as most data were not nor- mally distributed. The non-significant denitrification and DNRA rates in April, May, and November (see Section 3.3) were represented in the analysis by zero values, which led to the same results as when using theoretical rates at the limit of ${ }^{15} \mathrm{~N}-\mathrm{N}_{2}$ determination. At the muddy site, the correlation analysis did not include data from November, when gas ebullition prevented measurement of rates (see Section 3.3). Analyses were done using R (v.3.1.1, R Core Team 2014), with a significance level of $\alpha=0.05$.

\section{RESULTS}

\subsection{Water column characteristics}

The water column was density-stratified from approximately mid-May to mid-September at both sites (Fig. 2). In September, stratification was already weakened, as indicated by the decreased density difference between surface and bottom waters (sandy site: $0.54 \mathrm{~kg} \mathrm{~m}^{-3}$; muddy site: $1.15 \mathrm{~kg} \mathrm{~m}^{-3}$ ), but first in October the water column was fully mixed again (Fig. 2).

The seasonal pattern of bottom water temperature, dissolved oxygen, and $\mathrm{NO}_{2}{ }^{-}+\mathrm{NO}_{3}{ }^{-}$concentrations was related to the reduced water mixing during density stratification (Fig. 3). Bottom water temperatures were far below surface water temperatures and increased only slowly from spring onwards until den-

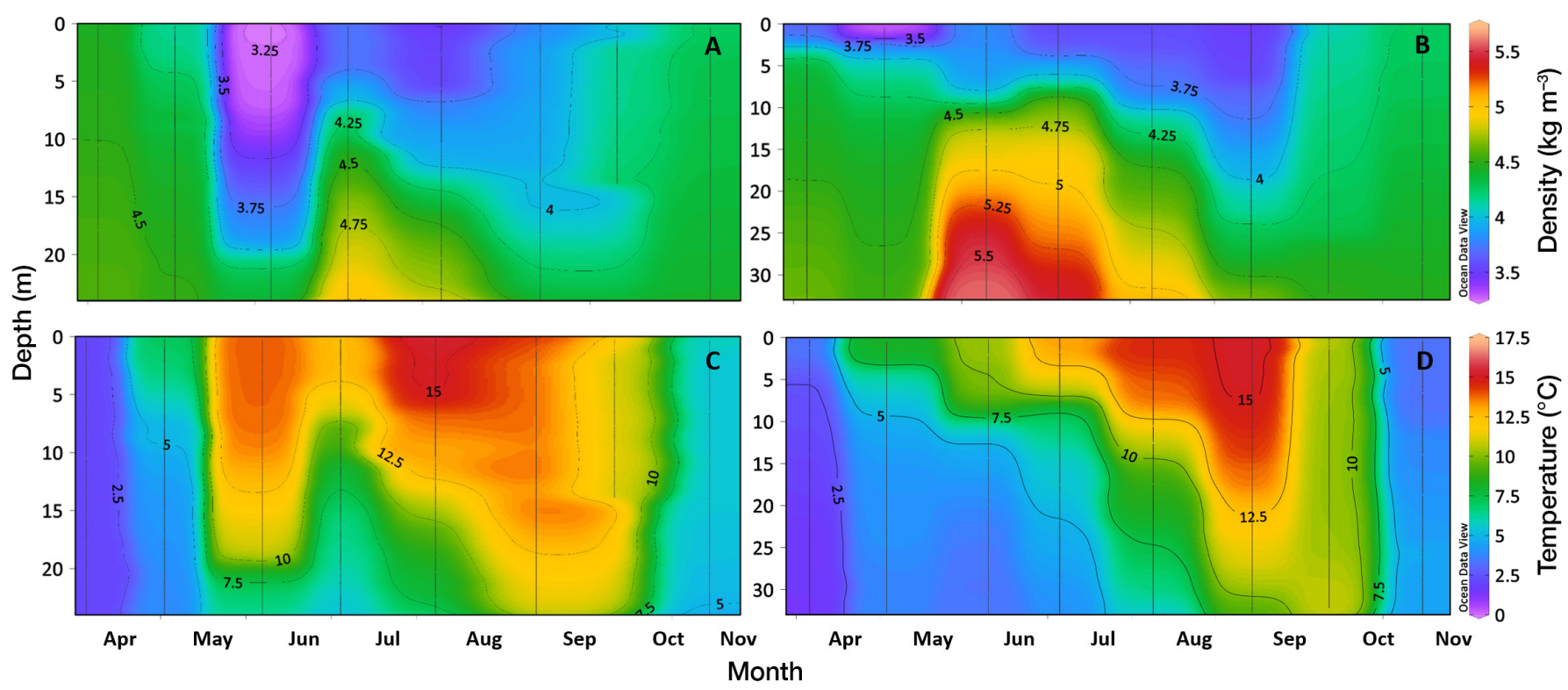

Fig. 2. Seasonal water column $(A, B)$ density $\left(\mathrm{kg} \mathrm{m}^{-3}\right)$ and $(C, D)$ temperature $\left({ }^{\circ} \mathrm{C}\right)$ from April to November at the $(A, C)$ sandy $(24 \mathrm{~m})$ and $(B, D)$ muddy $(33 \mathrm{~m})$ sites. Data are extrapolated from 1 CTD profile $\mathrm{mo}^{-1}$ (weighted-average gridding, quality limit 3 , linear color scale) using Ocean Data View (Schlitzer 2015). Notice different depth scales between sites 
sity stratification broke in early autumn, resulting in peak bottom water temperatures in September (sandy site) and October (muddy site; Figs. 2 \& 3). As the peak temperature at the sandy site was measured when the water column was still weakly stratified (Fig. 2), it is likely that temperatures continued to increase until full mixing of the water column between September and October, which, however, was not captured by our monthly measurement resolution. Bottom water dissolved oxygen concentrations decreased with the start and increased with the end of density stratification (Fig. 3), while bottom waters always remained oxic (sandy site: $\geq 226 \mu \mathrm{M}_{\text {; }}$ muddy site: $\geq 114 \mu \mathrm{M})$. Bottom water $\mathrm{NO}_{2}{ }^{-}+\mathrm{NO}_{3}{ }^{-}$concentrations decreased strongly in May $(\leq 0.2 \mu \mathrm{M})$ before the onset of stratification and remained low during the summer until increasing again from September onwards (Fig. 3). Bottom water $\mathrm{NH}_{4}{ }^{+}$concentrations did not follow a clear seasonal pattern, but were highest in September at both sites (Fig. 3).

The average bottom current velocity at the sandy site was lower in spring than in winter, while the dominant current directions were similar (Table 2). The average bottom water turbidity was low until mid-May (13 May 2016), when it increased rapidly $\sim 19$ fold and remained this high until the end of measurements (Table 2, Fig. S2).

\subsection{Sediment characteristics}

The sandy sediment consisted of silty fine sand with small stones in the surface layer. It had a permeability of $1.6-2.3 \times 10^{-12} \mathrm{~m}^{2}$ (Table 1 ) and was therefore not permeable enough for advective pore-water flow with significant effects on sediment biogeochemistry, in accordance with many Baltic sands (Forster et al. 2003, Hellemann et al. 2017, Bartl et al. 2019). Only bottom flow velocities $\geq 14 \mathrm{~cm} \mathrm{~s}^{-1}$ could theoretically have created pressure gradients high enough to overcome the low sediment permeability and lead to pore-water flow (Table S1). As such flow velocities were recorded only rarely in winter (Table 2), no advective pore-water flow took place in the period covered in this study.

Porosity, LOI, DOU, the deep $\mathrm{NH}_{4}{ }^{+}$sediment pool, $\mathrm{NH}_{4}{ }^{+}$fluxes (spring to late summer; all Table 1), and potential ammonification rates (Fig. 4) were notably lower in the sandy than in the muddy sediment. In contrast, the OPD was similar in both sediment types (Table 1), which might indicate a loss of oxygen from the sandy samples before concentration profiling. OPD decreased steeply from April-June, remained low until October, and increased again in November; DOU generally mirrored this pattern (Table 1).
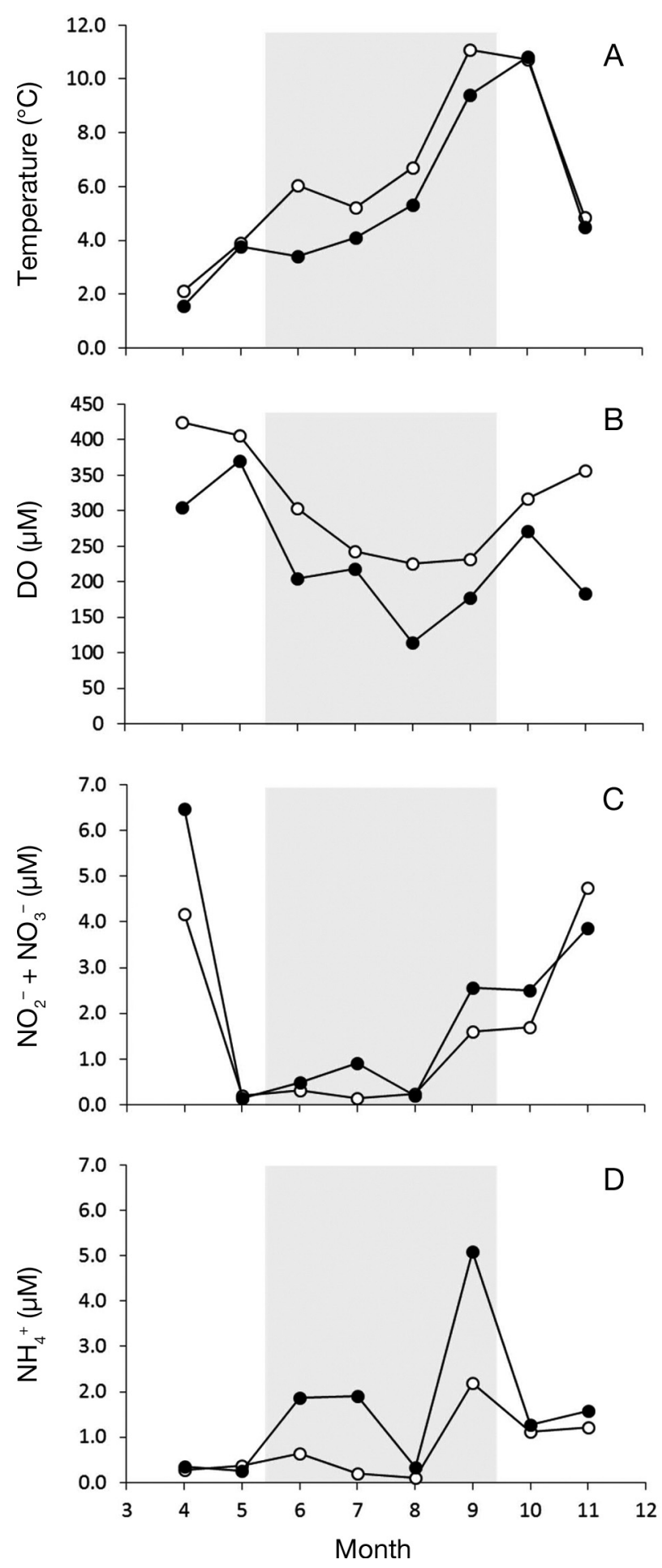

Fig. 3. Seasonal (A) temperature and concentrations of (B) dissolved oxygen (DO), (C) nitrite + nitrate $\left(\mathrm{NO}_{2}{ }^{-}+\mathrm{NO}_{3}{ }^{-}\right)$and (D) ammonium $\left(\mathrm{NH}_{4}{ }^{+}\right)$from April to November in the bottom water of the sandy (white circles) and muddy (black circles) sites. Shaded area: estimated period of water column stratification 
Table 2. Bottom water current velocity (average \pm SD and number of replicates in brackets, minimum, and maximum with $\%$ share of total measurements $>14 \mathrm{~cm} \mathrm{~s}^{-1}$ in brackets), main current directions (with \% share of total measurements in brackets; note that direction gives the destination of the water current, opposite to direction in meteorology), and turbidity (average $\pm \mathrm{SD}$ and number of replicates in brackets) in winter and spring at $\sim 1 \mathrm{~m}$ above the sea floor at the sandy site. Measurements in spring are divided into 2 phases based on strongly increasing turbidity starting from 13 May 2016

\begin{tabular}{|c|c|c|c|c|c|c|}
\hline \multirow{2}{*}{ Season } & \multirow[t]{2}{*}{ Time period } & \multicolumn{3}{|c|}{ - Current velocity $\left(\mathrm{cm} \mathrm{s}^{-1}\right)$} & \multirow{2}{*}{ Main current directions } & \multirow{2}{*}{$\begin{array}{c}\text { Turbidity } \\
\text { (FTU) }\end{array}$} \\
\hline & & Average & Minimum & Maximum & & \\
\hline Winter & $\begin{array}{l}15 \text { Dec } 2015- \\
14 \text { Jan } 2016\end{array}$ & $\begin{array}{c}4.0 \pm 2.3 \\
(10305)\end{array}$ & 0.2 & $\begin{array}{c}16.0 \\
(>14.0: 0.03 \%)\end{array}$ & $\begin{array}{l}\text { N, NNE, NE } \\
(35 \%)\end{array}$ & $\begin{array}{c}2.1 \pm 1.5 \\
(10305)\end{array}$ \\
\hline Spring I & $\begin{array}{l}5 \text { Apr 2016- } \\
12 \text { May } 2016\end{array}$ & $\begin{array}{c}2.7 \pm 1.7 \\
(13588)\end{array}$ & 0.1 & $\begin{array}{c}12.7 \\
(>14.0: 0.00 \%)\end{array}$ & $\begin{array}{c}\text { NE, ENE, E } \\
(29 \%)\end{array}$ & $\begin{array}{l}1.2 \pm 0.6 \\
(13588)\end{array}$ \\
\hline Spring II & $\begin{array}{l}13 \text { May 2016- } \\
7 \text { Jun } 2016\end{array}$ & $\begin{array}{c}2.1 \pm 1.2 \\
(8800)\end{array}$ & 0.1 & $<10.0$ & & $\begin{array}{c}22.2 \pm 9.8 \\
(8800)\end{array}$ \\
\hline
\end{tabular}

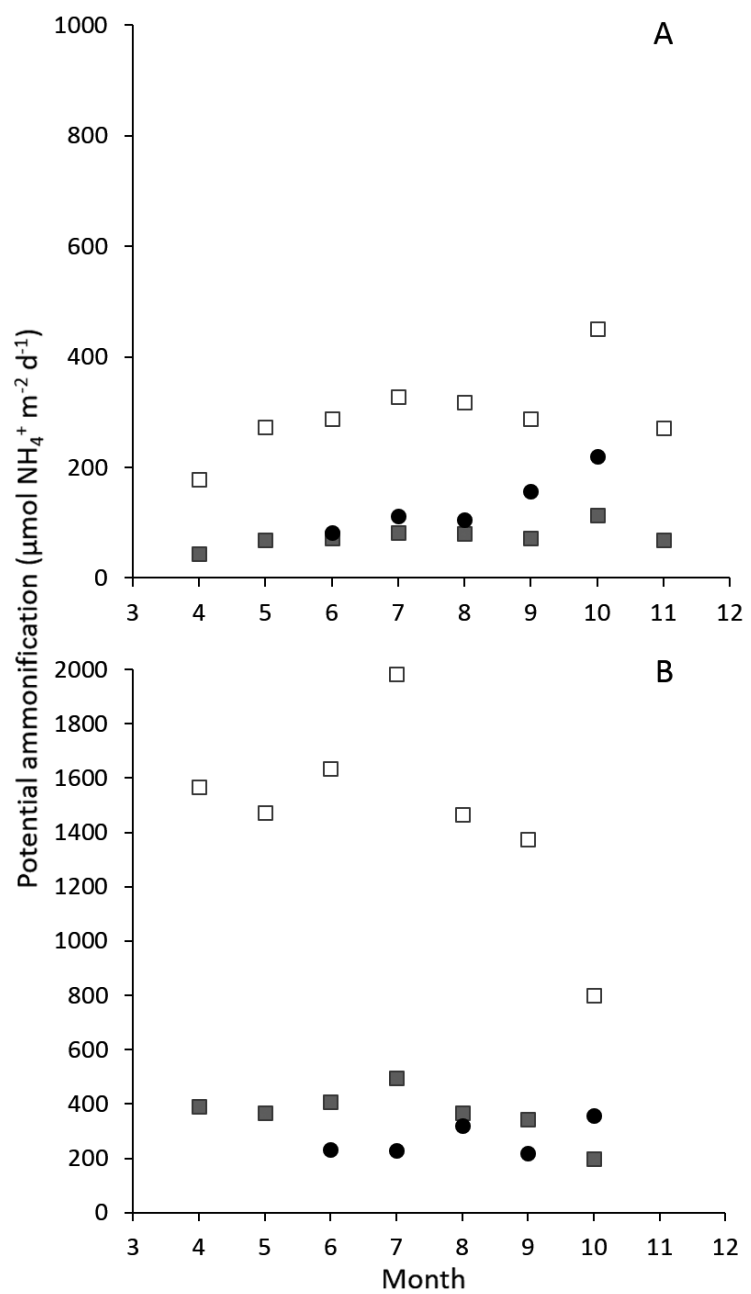

Fig. 4. Seasonal rates of potential ammonification in the (A) sandy and (B) muddy sediment, estimated from diffusive oxygen uptake divided by carbon to nitrogen ratios of 5 (white squares) and 20 (grey squares), assuming a 1:1 stoichiometry of oxygen and carbon dioxide. Black circles: combined nitrate reduction of denitrification and dissimilatory nitrate reduction to ammonium (DNRA) coupled to nitrification in the sediment $\left(D_{\mathrm{n}}+\mathrm{DNRA}_{\mathrm{n}}\right)$, which equals the minimum estimate of ammonium uptake in nitrification. Note the different scales between the sites

\subsection{Denitrification and DNRA}

In early spring, labelled $\mathrm{N}_{2}$ production $\left({ }^{29,30} \mathrm{~N}_{2}\right)$ at both sites was below (April) or at (May) the limit of determination $\left({ }^{29} \mathrm{~N}_{2}=0.00734 \mu \mathrm{M},{ }^{30} \mathrm{~N}_{2}=0.00017 \mu \mathrm{M}\right.$; calculated from $\mathrm{N}_{2}$ background values as average $+2 \times \mathrm{SD}$ ). This led to zero (April) or very low (May) ${ }^{29,}{ }^{30} \mathrm{~N}_{2}$ concentrations, whereby the latter did not increase over incubation time (maximum $10 \mathrm{~h}$ ) and ${ }^{15} \mathrm{~N}-\mathrm{N}_{2}$ production rates did not depend on added tracer concentrations (Fig. S1), in sum indicating inactivity of denitrification bacteria. From JuneOctober, ${ }^{29,}{ }^{30} \mathrm{~N}_{2}$ production was above the limit of determination, ${ }^{29,30} \mathrm{~N}_{2}$ concentrations increased over incubation time, and ${ }^{15} \mathrm{~N}-\mathrm{N}_{2}$ production rates depended on added tracer concentrations; hence, denitrification bacteria were active (Fig. S1). Denitrification rates increased significantly from June onwards, reaching maximum values in September (sandy site: $91 \pm 17 \mu \mathrm{mol} \mathrm{N} \mathrm{m}{ }^{-2} \mathrm{~d}^{-1}$ ) and October (muddy site: $263 \pm 68 \mu \mathrm{mol} \mathrm{N} \mathrm{m}{ }^{-2} \mathrm{~d}^{-1}$; Fig. 5). In November, ${ }^{29,}{ }^{30} \mathrm{~N}_{2}$ production was again at the determination limit at the sandy site, whereas samples from the muddy site were destroyed by gas ebullition. It is likely that those samples would have yielded measurable denitrification rates if undisturbed, as the previous month's rates were still high, and high rates in November and December have been reported earlier at this site (Hietanen \& Kuparinen 2008, Jäntti et al. 2011). Rates at the sandy site were $\sim 50-80 \%$ lower than at the muddy site. At both sites, denitrification was mainly coupled to nitrification in the sediment $\left(D_{\mathrm{n}}=88-\right.$ $99 \%$; Fig. 5). This also indicates that the potential shoaling of OPD in the sandy sediment (see Section 3.2) may not have affected sediment $\mathrm{N}$ cycling strongly, as the denitrification pathway did not shift to $D_{\mathrm{w}}$ in response to a shallower oxic sediment layer (Rysgaard et al. 1994). Both $D_{\mathrm{n}}$ and $D_{\mathrm{w}}$ correlated 


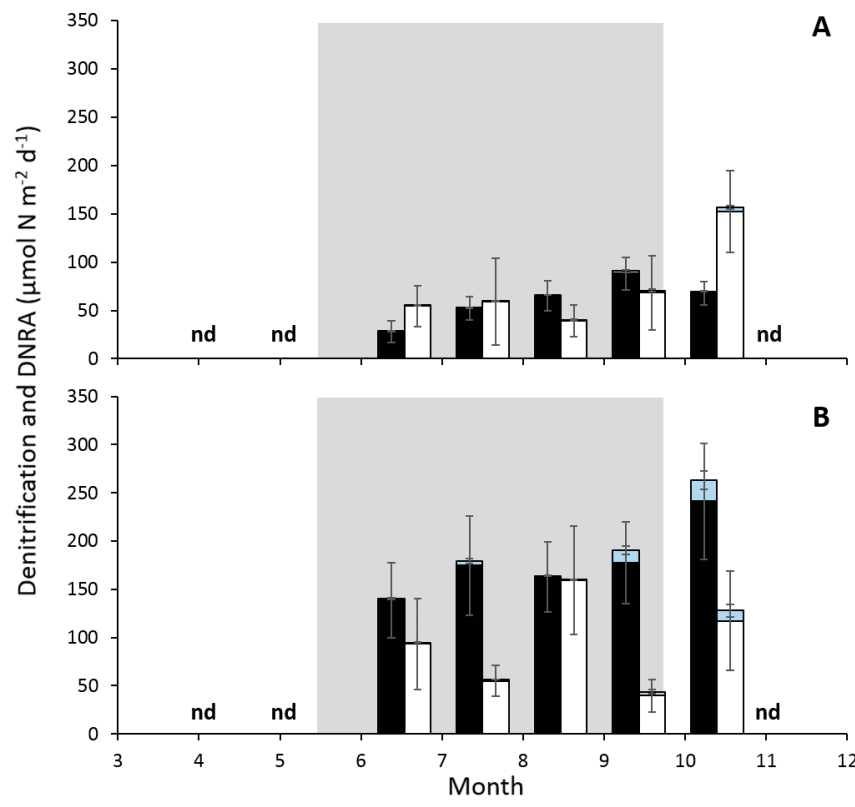

Fig. 5. Seasonal rates of benthic denitrification (black) and dissimilatory nitrate reduction to ammonium (DNRA; white) at the (A) sandy and (B) muddy sites from April to November 2016, given as share of rates using nitrate from nitrification in the sediment (black/white bars) and nitrate from the near-bottom water (light blue bars). Data are shown as averages $\pm \mathrm{SD}$; nd: not detectable. Shaded area: estimated period of water column stratification

positively with bottom water temperature, whereas no correlation was found with LOI or bottom water $\mathrm{NO}_{2}{ }^{-}+\mathrm{NO}_{3}{ }^{-}$(Table 3).

DNRA rates could not be calculated in April, May, and November due to the insignificant ${ }^{29,30} \mathrm{~N}_{2}$ production in these months and the subsequent lack of ${ }^{29 / 30} \mathrm{~N}_{2}$ ratio needed for the calculations. In the remaining months, DNRA rates did not show a consistent seasonal trend at either site. At the sandy site, rates were nearly constant except for a single peak in October $\left(157 \pm 43 \mu \mathrm{mol} \mathrm{N} \mathrm{m}^{-2} \mathrm{~d}^{-1}\right)$, while at the muddy site, rates varied strongly with the highest rate measured in August $\left(160 \pm 56 \mu \mathrm{mol} \mathrm{N} \mathrm{m}{ }^{-2}\right.$ $\mathrm{d}^{-1}$; Fig. 5). On average, DNRA rates were $\sim 20 \%$ lower in the sandy than in the muddy sediment. However, the average share of DNRA in total $\mathrm{NO}_{3}{ }^{-}$ reduction was $\sim 20 \%$ higher in the sandy $(\sim 54 \%)$ than in the muddy $(\sim 33 \%)$ sediment. At both sites, DNRA was mainly coupled to nitrification in the sediment (DNRA $:$ 90-99\%; Fig. 5). At the sandy site, both $\mathrm{DNRA}_{n}$ and
DNRA $_{\mathrm{w}}$ correlated positively with bottom water temperature, while at the muddy site only DNRA $_{\mathrm{w}}$ correlated positively with bottom water temperature and DNRA $_{n}$ correlated positively with LOI (Table 3).

\section{DISCUSSION}

\subsection{Seasonal cycle of denitrification and DNRA}

Seasonal denitrification rates were linked to the hydrography-related development of bottom water temperature, which was similar at both sites located below the thermocline, explaining the observed similar seasonality in both sediment types. As temperature generally promotes microbial activity by increasing metabolic rates as well as the diffusive transport of substrates, the positive effect on denitrification rates was expected (Rysgaard et al. 2004). Temperature was the only factor correlating positively with denitrification rates at both sites, in contrast to previous studies that found additional correlations with LOI (Jäntti et al. 2011) and bottom water $\mathrm{NO}_{2}{ }^{-}+\mathrm{NO}_{3}{ }^{-}$concentrations (Hietanen \& Kuparinen 2008). However, LOI in this study increased only weakly (muddy site) or not at all (sandy site) over the seasonal cycle, and bottom water $\mathrm{NO}_{2}{ }^{-}+\mathrm{NO}_{3}{ }^{-}$concentrations were, after a rapid drawdown between April and May, already very low before the onset of measurable denitrification rates in June (Figs. 3 \& 5); they remained low throughout the summer and hence could not strongly support denitrification

Table 3. Correlation of the environmental parameters bottom water temperature, nitrate + nitrite $\left(\mathrm{NO}_{3}{ }^{-}+\mathrm{NO}_{2}{ }^{-}\right)$and ammonium $\left(\mathrm{NH}_{4}{ }^{+}\right)$, and sediment loss on ignition (LOI), oxygen penetration depth (OPD), diffusive oxygen uptake (DOU), and surface $\mathrm{NH}_{4}{ }^{+}$pool (1 cm depth integrated) with rates of denitrification and dissimilatory nitrate reduction to ammonium (DNRA) at the sandy and muddy sites, using Kendall's tau for non-parametric data computed with R. $D_{\mathrm{w}}, \mathrm{DNRA}_{\mathrm{w}}$ : denitrification, DNRA of nitrate from the water column; $D_{\mathrm{n}}$, DNRA $_{n}$ : denitrification, DNRA of nitrate from nitrification within the sediment. ${ }^{*} \mathrm{p}<0.05 ;{ }^{* *} \mathrm{p}<0.01{ }^{* * *} \mathrm{p}<0.001$

\begin{tabular}{|c|c|c|c|c|c|c|c|c|}
\hline \multirow{2}{*}{ Site } & \multirow[t]{2}{*}{ Variables } & \multicolumn{3}{|c|}{ Bottom water -} & \multicolumn{4}{|c|}{ - Sediment } \\
\hline & & $\begin{array}{l}\text { Temp- } \\
\text { erature }\end{array}$ & $\begin{array}{l}\mathrm{NO}_{3}^{-} \\
+\mathrm{NO}_{2}^{-}\end{array}$ & $\mathrm{NH}_{4}^{+}$ & LOI & OPD & DOU & $\begin{array}{c}\text { Surface } \\
\mathrm{NH}_{4}^{+} \text {pool }\end{array}$ \\
\hline \multirow[t]{4}{*}{ Sand } & $D_{\mathrm{w}}$ & $0.95^{* * *}$ & -0.04 & 0.19 & -0.11 & -0.49 & 0.57 & 0.04 \\
\hline & $D_{\mathrm{n}}$ & $0.87^{* *}$ & -0.11 & 0.11 & -0.04 & -0.57 & $0.64^{*}$ & 0.11 \\
\hline & $\mathrm{DNRA}_{\mathrm{w}}$ & $0.79^{* *}$ & 0.11 & 0.19 & -0.11 & -0.34 & 0.57 & 0.04 \\
\hline & $\mathrm{DNRA}_{\mathrm{n}}$ & $0.64^{*}$ & -0.04 & 0.19 & -0.11 & -0.49 & $0.72^{*}$ & 0.19 \\
\hline \multirow[t]{4}{*}{ Mud } & $D_{\mathrm{w}}$ & $0.68^{*}$ & 0.39 & 0.59 & 0.29 & $-0.78^{*}$ & -0.29 & -0.49 \\
\hline & $D_{\mathrm{n}}$ & $0.78^{*}$ & 0.29 & 0.49 & 0.39 & $-0.68^{*}$ & -0.39 & -0.59 \\
\hline & $\mathrm{DNRA}_{\mathrm{w}}$ & $0.68^{*}$ & 0.39 & 0.59 & 0.29 & $-0.78^{*}$ & -0.29 & -0.49 \\
\hline & $\mathrm{DNRA}_{\mathrm{n}}$ & 0.39 & -0.29 & -0.10 & $0.78^{*}$ & -0.49 & -0.20 & $-0.78^{*}$ \\
\hline
\end{tabular}


rates, which was verified by the minor share of denitrification using bottom water $\mathrm{NO}_{3}{ }^{-}\left(D_{\mathrm{w}}=1-12 \%\right)$.

The observed drawdown of water column $\mathrm{NO}_{2}{ }^{-}+$ $\mathrm{NO}_{3}{ }^{-}$was associated with a developing spring bloom in surface waters, which was corroborated by chlorophyll a concentrations (muddy site only; S. Elovaara unpubl. data). Bloom material reached the benthic system of both sites between May and June, as suggested by a $15 \%$ increase in LOI at the muddy site (Table 1) and a strong increase in bottom water turbidity suggesting particle accumulation (Fig. S2; Azetsu-Scott \& Johnson 1994) at the sandy site. In the same period, oxygen uptake in the sediment and $\mathrm{NH}_{4}{ }^{+}$concentrations in the bottom water increased slightly at both sites, while no strong increase in bottom water temperature occurred, indicating mineralization. Hence, while we lack information on the identity and thus characteristics of the settled material (e.g. C:N ratio), it very likely originated from the spring bloom and therefore can be expected to be of labile, easily degradable phytoplankton origin. The timing of benthic availability of this organic matter coincides with denitrification rates becoming measurable in June in both sediments, suggesting that denitrification had been limited by labile organic carbon availability in the months before the spring bloom input, as described in previous studies (Slater \& Capone 1987, Bradley et al. 1992, Hietanen \& Kuparinen 2008, Taylor \& Townsend 2010, Jäntti et al. 2011, Hellemann et al. 2017). Despite lacking statistical evidence, this suggests that not only bottom water temperature, but also labile organic matter availability affected the seasonal pattern of denitrification in both sediments.

The observed seasonal pattern of denitrification in both aphotic sediment types agrees with previous observations from the aphotic, seasonally stratified Baltic coast (Hietanen \& Kuparinen 2008, Jäntti et al. 2011, Bonaglia et al. 2014) and strongly contrasts with observations from the photic, hydrographically mixed Baltic coast (e.g. Jørgensen \& Sørensen 1985, Nielsen et al. 1995). This is particularly obvious in early spring, when low substrate availability limits denitrification rates in the aphotic coastal sediments, while rates in the photic coastal sediments can already peak, independent of the sediment type. Interestingly, the seasonal pattern of denitrification in sediments of the open Baltic Sea is similar to the described pattern here at the aphotic coast, although the reasons are unclear (Tuominen et al. 1998).

Unlike denitrification, DNRA rates did not follow a clear seasonal pattern and did not correlate consistently with any of the environmental parameters. For instance, DNRA rates at the sandy site were significantly related to bottom water temperature, whereas rates at the muddy site were significantly related to organic matter content. The latter suggests that DNRA at the muddy site was heterotrophic, which was corroborated by having no significant correlation with pore-water $\mathrm{H}_{2} \mathrm{~S}$ concentrations as indicator of chemolithotrophy (data not shown, S. Hietanen unpubl. data; Kendall's tau, p = 0.483). While no porewater $\mathrm{H}_{2} \mathrm{~S}$ data are available from the sandy sediment, no $\mathrm{H}_{2} \mathrm{~S}$ odor was noticed there either; hence, we assume that DNRA was heterotrophic in both sediments. Consequently, it is possible that DNRA activity was limited by labile organic carbon availability in the same months as denitrification, whereas DNRA competed with denitrification for the same electron donor (organic carbon) and acceptor $\left(\mathrm{NO}_{3}{ }^{-}\right)$in the remaining months (Tiedje 1988, Kraft et al. 2014); this likely affected the partitioning between both processes and contributed to the observed seasonal pattern. For instance, despite the correlation with bottom water temperature and similar peak temperatures in September $\left(11.1^{\circ} \mathrm{C}\right)$ and October $\left(10.1^{\circ} \mathrm{C}\right.$; Fig. 3) at the sandy site, DNRA rates only peaked in October when denitrification rates were low, whereas denitrification rates peaked in September when DNRA rates were low (Fig. 5). In contrast, the highest DNRA rates at the muddy site co-occurred with high denitrification rates, potentially indicating less substrate competition than at the sandy site. Altogether, we suggest that the seasonal cycle of DNRA is driven by a combination of factors (bottom water temperature, electron donor to acceptor ratio, substrate competition with denitrification), which, however, cannot be clearly distinguished with the available data.

\subsection{Site-specific denitrification and DNRA rates}

Denitrification and DNRA rates were far lower in the sandy than in the muddy sediment, most likely due to a lower availability of labile organic matter as a source of organic carbon and N (Finlay et al. 2013, Bartl et al. 2019). The sandy sediment contained $<8 \%$ of the organic matter measured in the muddy sediment, although pelagic primary production can be expected to have been similar at both sites (Fig. 1) and the sandy sediment was not permeable enough for advective pore-water flow, the common reason for low organic content in sands (Boudreau et al. 2001). Hence, we assume that the sandy sediment received only limited organic matter due to its location on an exposed transportation bottom. While the bottom 
flow velocity was too low to create pore-water flow in the low permeable sand, it was nevertheless higher than the maximum community sinking rate of a typical coastal spring bloom (0.15 $\mathrm{cm} \mathrm{s}^{-1}$; Riebesell 1989) and thus may have contributed to horizontal drift of phytoplankton with the bottom current, exporting it from the site (Reigstad \& Wassmann 1996). And while bottom flow velocities can be similar at the muddy site (Niemistö \& Lund-Hansen 2019), its basin-like geomorphology largely prevents export of organic matter with the bottom current, as indicated by the large LOI and deep $\mathrm{NH}_{4}{ }^{+}$pool (Table 1). As organic matter content and grain size also affect the in situ faunal community (Joensuu et al. 2018), differences in faunal communities likely added to the different rates between sites.

The low amount of organic matter and correspondingly small pool of labile organic carbon in the sandy sediment might also explain why denitrification rates were again limited in November. Interestingly, despite the low amount of organic matter and small theoretical $\mathrm{NH}_{4}{ }^{+}$surplus from potential ammonification (Fig. 4), the deep $\mathrm{NH}_{4}{ }^{+}$pool in the sandy sediment was comparatively large, which might have resulted from DNRA. We estimated that the average measured DNRA rate of $\sim 77 \mu \mathrm{mol} \mathrm{N} \mathrm{m} \mathrm{N}^{-2} \mathrm{~d}^{-1}$ could have filled the average deep $\mathrm{NH}_{4}{ }^{+}$pool in less than a month (23 d).

The denitrification rates measured in the sandy sediment were similar to the lowest rates measured in Arctic aphotic sands (Greenland shelf; Rysgaard et al. 2004) and lower than in Baltic aphotic sands of an oligotrophic estuary (Öre Estuary, Gulf of Bothnia: $140 \mu \mathrm{mol} \mathrm{N} \mathrm{m} \mathrm{N}^{-2} \mathrm{~d}^{-1}$ in summer; Hellemann et al. 2017), which, however, has a much larger particle residence time ( $\geq 1 \mathrm{yr}$; Brydsten \& Jansson 1989) than the site studied here. The DNRA rates in the sandy sediment were in a similar range to rates from the intertidal, permeable Janssand (German Wadden Sea), including sulfidic (Behrendt et al. 2013) and non-sulfidic (Marchant et al. 2014) conditions, despite the lack of $\mathrm{H}_{2} \mathrm{~S}$ in our samples. The denitrification rates measured in the muddy sediment agreed well with previous measurements at the same site (Hietanen \& Kuparinen 2008, Jäntti et al. 2011), but were lower than in other, more eutrophic, aphotic muddy sediments of the coastal Baltic Sea (Aarhus Bay, western Belt Sea: $500 \mu \mathrm{mol} \mathrm{N} \mathrm{m}{ }^{-2} \mathrm{~d}^{-1}$, Nielsen \& Glud 1996; Paimionlahti Estuary, southern Gulf of Bothnia: $910 \mu \mathrm{mol} \mathrm{N} \mathrm{m}{ }^{-2} \mathrm{~d}^{-1}$, Ahvenkoskenlahti Estuary, northern Gulf of Finland: $320 \mu \mathrm{mol} \mathrm{N} \mathrm{m}{ }^{-2} \mathrm{~d}^{-1}$, Silvennoinen et al. 2007; Himmerfjärden Estuary, western Baltic Proper: $360 \mu \mathrm{mol} \mathrm{N} \mathrm{m}{ }^{-2} \mathrm{~d}^{-1}$, Bonaglia et al. 2014; all rates are maxima of comparable time periods).
The DNRA rates in the muddy sediment were lower than rates measured in muds with highly refractory organic matter content (Råne river mouth, Bothnian Bay: $270 \mu \mathrm{mol} \mathrm{N} \mathrm{m}{ }^{-2} \mathrm{~d}^{-1}$; Bonaglia et al. 2017) and very eutrophic conditions (inner Himmerfjärden Estuary: $720 \mu \mathrm{mol} \mathrm{N} \mathrm{m}^{-2} \mathrm{~d}^{-1}$; Bonaglia et al. 2014), but higher than in muds of moderate eutrophic conditions (outer Himmerfjärden Estuary: <17 $\mu$ mol $\mathrm{N}$ $\mathrm{m}^{-2} \mathrm{~d}^{-1}$; Bonaglia et al. 2014). The DNRA rates were also higher than previously measured at the same site (<50 $\mu \mathrm{mol} \mathrm{N} \mathrm{m} \mathrm{N}^{-2} \mathrm{~d}^{-1}$; Jäntti et al. 2011), but those rates are possibly underestimated as the particleattached ${ }^{15} \mathrm{~N}-\mathrm{NH}_{4}{ }^{+}$was not extracted during analysis.

\subsection{Contribution of DNRA to total nitrate reduction}

While DNRA rates were lower in the sandy than the muddy sediment, the share of DNRA in total $\mathrm{NO}_{3}{ }^{-}$reduction was higher and presented, with on average $50 \%$, the highest share so far measured in sandy sediments (Behrendt et al. 2013, Erler et al. 2014, Marchant et al. 2014). This is a striking result, as DNRA is generally considered to be of negligible importance in sands. Despite being lower than in the sandy sediment, the share of DNRA in the muddy sediment still accounted for $\sim 30 \%$ of total $\mathrm{NO}_{3}{ }^{-}$ reduction, which is a high contribution compared to previous studies from cold muddy sediments (Binnerup et al. 1992, Jäntti et al. 2011, Crowe et al. 2012, Behrendt et al. 2013, Bonaglia et al. 2014), but agrees with recent measurements in a cold muddy sediment at the Baltic Sea coast (Råne river mouth, Bothnian Bay; Bonaglia et al. 2017). With DNRA assumed to be heterotrophic, the partitioning with denitrification was likely driven by competition for the substrate organic carbon and $\mathrm{NO}_{3}{ }^{-}$(Tiedje 1988, Kraft et al. 2014). At the sandy site, the low substrate availability seems to not have favored either process, leading to nearly equal partitioning; at the muddy site, the high substrate availability of largely labile, phytoplankton origin seems to have favored denitrification (Kraft et al. 2014), however not strongly as the DNRA contribution was still high. Clearly, a better identification of the organic matter quality is needed to reasonably explain our results.

In regard to the $\mathrm{N}$ filter function of coastal sediments, the observed process partitioning suggests that the sandy sediment removed and retained approximately the same amount of $\mathrm{N}$, whereas the muddy sediment removed more $\mathrm{N}$ than it retained. However, when using the combined rates of denitri- 
fication and DNRA coupled to nitrification in the sediment $\left(D_{\mathrm{n}}+\mathrm{DNRA}_{\mathrm{n}}\right)$ as minimum estimate of nitrification (i.e. the oxidation of $\mathrm{NH}_{4}{ }^{+}$to $\mathrm{NO}_{3}{ }^{-}$) and comparing this to the potential ammonification rates based on organic matter availability, a large surplus of $\mathrm{NH}_{4}{ }^{+}$ is visible at the muddy site (Fig. 4). This $\mathrm{NH}_{4}{ }^{+}$might leave the sediment as $\mathrm{NH}_{4}{ }^{+}$or $\mathrm{NO}_{3}{ }^{-}$(after oxidation), or accumulate in the deep $\mathrm{NH}_{4}{ }^{+}$pool; either way, this surplus of $\mathrm{N}$ remains bioavailable in the benthic system. This means that the muddy sediment in fact retained more $\mathrm{N}$ than it removed and more than the sandy site (Fig. 6). While $\mathrm{N}$ retention is part of the coastal filter function (Asmala et al. 2017), it can foster eutrophication of the coastal filter itself, which seems to be facilitated under already organic-rich conditions.

\section{CONCLUSIONS}

The seasonal pattern of benthic denitrification in the aphotic, density-stratified coastal zone of the
Baltic Sea was mainly driven by the seasonal hydrography pattern and therefore similar between different sediment types located below the thermocline, whereas denitrification rates per se were related to substrate availability and therefore differed between sediment types. While these results are based on 2 sites only, not allowing for representative generalizations, they nevertheless fit to previous observations and thus add further evidence that the seasonality of benthic denitrification differs between the aphotic, stratified and the photic, mixed coastal zone of the Baltic Sea. Future studies should differentiate between these coastal zones, as their specific hydrography and light conditions might affect biogeochemical element cycling beyond only $\mathrm{N}$ removal.

Our data also support previously published work stating that DNRA can indeed be significant in cold and sandy sediments. However, many key questions, particularly regarding the drivers of DNRA in these environments, remain open and can only be addressed by more DNRA quantifications in both sandy and
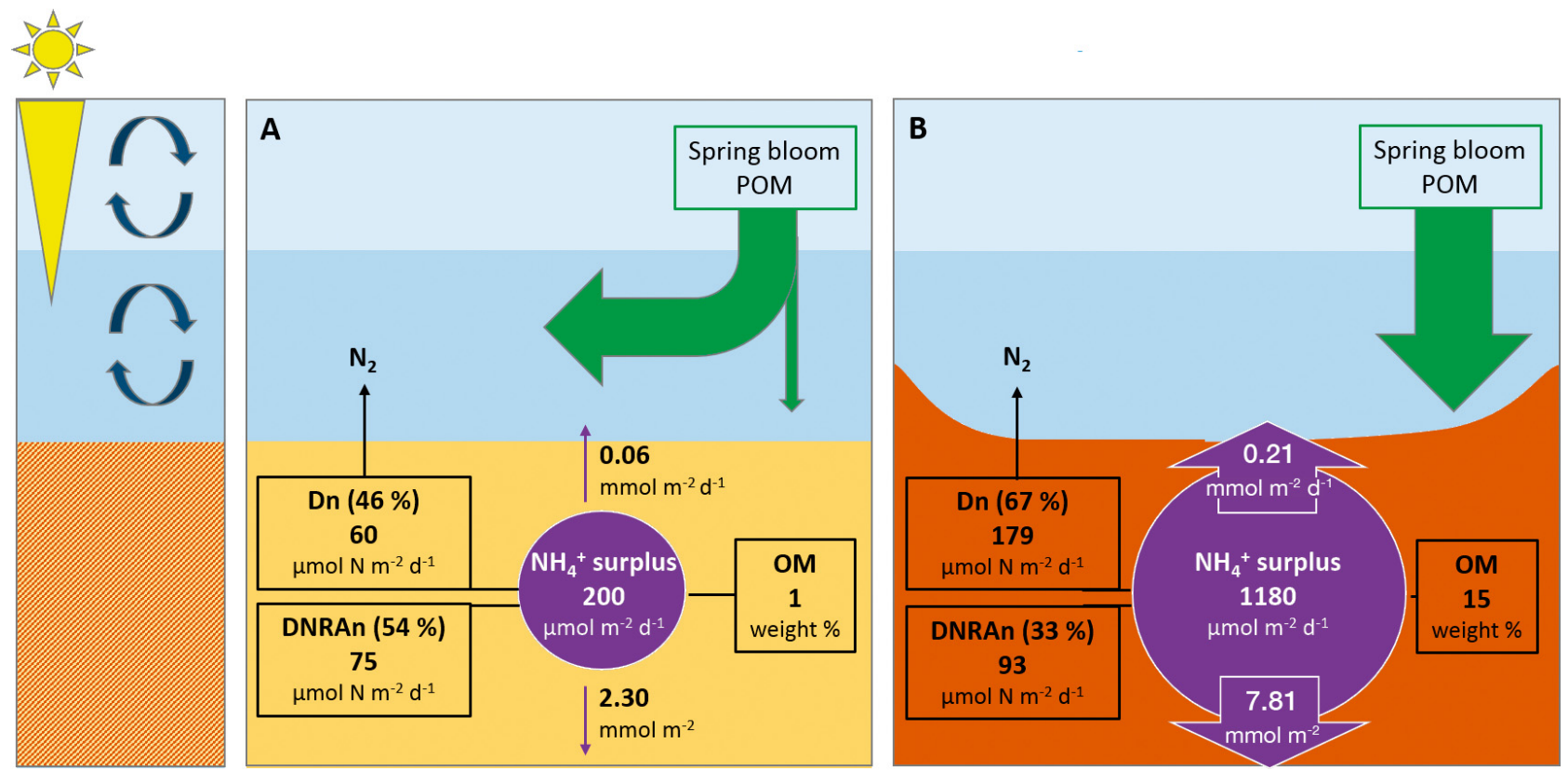

Fig. 6. Visualization of the coastal nitrogen (N) 'filter' at the studied (A) sandy and (B) muddy sites in the aphotic, seasonally stratified coastal zone of the Baltic Sea. Numbers are averages of all months. The ammonium $\left(\mathrm{NH}_{4}{ }^{+}\right)$surplus is calculated from potential ammonification rates of labile organic matter (OM; carbon to nitrogen ratio of 5, see Section 2.3) and from a minimum estimate of $\mathrm{NH}_{4}{ }^{+}$consumption in nitrification, inferred from denitrification $\left(D_{\mathrm{n}}\right)$ and dissimilatory nitrate reduction to ammonium $\left(\right.$ DNRA $\left._{n}\right)$ coupled to nitrification in the sediment. While it is likely that more $\mathrm{NH}_{4}{ }^{+}$would be consumed in nitrification and subsequently leave the sediment as nitrate $\left(\mathrm{NO}_{3}{ }^{-}\right)$, thereby reducing the $\mathrm{NH}_{4}{ }^{+}$surplus, we have no data on $\mathrm{NO}_{3}{ }^{-}$fluxes and thus only consider minimum nitrification based on $D_{\mathrm{n}}$ and $\mathrm{DNRA}_{\mathrm{n}}$. Either way, the portion of bioavailable $\mathrm{N}$ remaining in the benthic system (either as $\mathrm{NH}_{4}{ }^{+}$or as $\mathrm{NO}_{3}{ }^{-}$) stays the same. Notice that the $\mathrm{NH}_{4}{ }^{+}$surplus is a theoretical consideration (see Section 2.3 and Fig. 4), and consequently, the numbers do not give a closed budget. (A) The sandy sediment contained very low OM due to location-specific limited sedimentation of phytoplankton particulate organic matter (POM), resulting in low $D_{\mathrm{n}}$ and DNRA ${ }_{\mathrm{n}}$ rates and only a small surplus of $\mathrm{NH}_{4}{ }^{+}$, which can explain the small $\mathrm{NH}_{4}{ }^{+}$pool in the sediment. (B) The muddy sediment contained 15 fold more OM than the sandy sediment, leading to higher $D_{\mathrm{n}}$ and DNRA $\mathrm{n}$ rates and a nearly 6 fold larger surplus of $\mathrm{NH}_{4}{ }^{+}$, which can explain the large $\mathrm{NH}_{4}{ }^{+}$pool in the sediment and the $\mathrm{NH}_{4}{ }^{+}$flux out of the sediment. Consequently, despite the larger removal of bioavailable $\mathrm{N}$ via denitrification, the muddy site nevertheless retained more bioavailable $\mathrm{N}$ than the sandy site 
cold environments. Improving our understanding of the role of DNRA in the coastal $\mathrm{N}$ filter is imperative for improving our understanding of coastal eutrophication dynamics; this applies particularly to the coastal zone of the Baltic Sea, where the DNRA process is still largely disregarded.

Acknowledgements. This work was supported by the BONUS COCOA project (grant agreement 2112932-1) funded jointly by the European Union and the Academy of Finland, the Academy of Finland (projects 267112, 272964, 303774, and 310302), the Onni Talas Foundation and the Finnish Cultural Foundation. We thank the Tvärminne Zoological Station for laboratory and technical support, and valuable marine infrastructure. Thanks to captain and crew of RV 'Saduria' (Göran Lundberg, Veijo Kinnunen, Hanna Halonen), as well as Mari Joensuu, Jukka-Pekka Myllykangas, Soila Silvonen and the many seasonal assistances for support in the field. Thanks to Franziska Thoms, Juha Niemistö, and Jukka Pajala for laboratory and logistical help, as well as to Heidi Petterson, Samu Elovaara, and Tom Jilbert for valuable discussions.

\section{LITERATURE CITED}

Al-Hamdani Z, Reker J (eds) (2007) Towards marine landscapes in the Baltic Sea. BALANCE interim report no. 10. Danish Forest and Nature Agency, Copenhagen

Asmala E, Carstensen J, Conley DJ, Slomp CP, Stadmark J, Voss M (2017) Efficiency of the coastal filter: nitrogen and phosphorus removal in the Baltic Sea. Limnol Oceanogr 62:S222-S238

Azetsu-Scott K, Johnson B (1994) Time series of the vertical distribution of particles during and after a spring phytoplankton bloom in a coastal basin. Cont Shelf Res 14: 687-705

Bartl I, Hellemann D, Rabouille C, Schulz K, Tallberg P, Hietanen S, Voss M (2019) Particulate organic matter controls benthic microbial $\mathrm{N}$ retention and $\mathrm{N}$ removal in contrasting estuaries of the Baltic Sea. Biogeosciences 16:3543-3564

Bear J (1972) Dynamics of fluids in porous media. American Elsevier, New York, NY

Behrendt A, de Beer D, Stief P (2013) Vertical activity distribution of dissimilatory nitrate reduction in coastal marine sediments. Biogeosciences 10:7509-7523

* Binnerup SJ, Jensen K, Revsbech NP, Jensen MH, Sørensen J (1992) Denitrification, dissimilatory reduction of nitrate to ammonium, and nitrification in a bioturbated estuarine sediment as measured with $\mathrm{N}^{15}$ and microsensor techniques. Appl Environ Microbiol 58:303-313

Bonaglia S, Deutsch B, Bartoli M, Marchant HK, Bruchert V (2014) Seasonal oxygen, nitrogen and phosphorus benthic cycling along an impacted Baltic Sea estuary: regulation and spatial patterns. Biogeochemistry 119: 139-160

Bonaglia S, Hylen A, Rattray JE, Kononets MY and others (2017) The fate of fixed nitrogen in marine sediments with low organic loading: an in situ study. Biogeosciences 14: 285-300

Boudreau BP (1997) Diagenetic models and their implementation. Springer, Berlin

Boudreau B, Huettel M, Forster S, Jahnke RA and others (2001) Permeable marine sediments: overturning an old paradigm. Eos (Wash DC) 82:133-136

Bradley PM, Fernandez M Jr, Chapelle FH (1992) Carbon limitation of denitrification rates in an anaerobic groundwater system. Environ Sci Technol 26:2377-2381

*Bydsten L, Jansson M (1989) Studies of estuarine sediment dynamics using ${ }^{137} \mathrm{Cs}$ from the Tjernobyl accident as a tracer. Estuar Coast Shelf Sci 28:249-259

Burdige D (2006) Geochemistry of marine sediments. Princeton University Press, Princeton, NJ

Christensen PB, Rysgaard S, Sloth NP, Dalsgaard T, Schwærter S (2000) Sediment mineralization, nutrient fluxes, denitrification and dissimilatory nitrate reduction to ammonium in an estuarine fjord with sea cage trout farms. Aquat Microb Ecol 21:73-84

* Conley DJ, Carstensen J, Aigars J, Axe P and others (2011) Hypoxia is increasing in the coastal zone of the Baltic Sea. Environ Sci Technol 45:6777-6783

* Crowe SA, Canfield DE, Mucci A, Sundby B, Maranger R (2012) Anammox, denitrification and fixed-nitrogen removal in sediments from the lower St. Lawrence Estuary. Biogeosciences 9:4309-4321

* Dalsgaard T, Thamdrup B, Canfield DE (2005) Anaerobic ammonium oxidation (anammox) in the marine environment. Res Microbiol 156:457-464

Erler DV, Santos IR, Zhang Y, Tait DR and others (2014) Nitrogen transformations within a tropical subterranean estuary. Mar Chem 164:38-47

Finlay JC, Small GE, Sterner RW (2013) Human influences on nitrogen removal in lakes. Science 342:247-250

Forster S, Bobertz B, Bohling B (2003) Permeability of sands in the coastal areas of the southern Baltic Sea: mapping a grain-size related sediment property. Aquat Geochem 9: $171-190$

KGiblin AE, Tobias CR, Song B, Weston N, Banta GT, RiveraMonroy VH (2013) The importance of dissimilatory nitrate reduction to ammonium (DNRA) in the nitrogen cycle of coastal ecosystems. Oceanography (Wash DC) 26:124-131

Grasshoff K, Ehrhardt M, Kremling K (1983) Methods of seawater analysis. Verlag Chemie, Weinheim

HELCOM (Helsinki Commission) (2015) Updated fifth Baltic Sea pollution load compilation (PLC-5.5). Baltic Sea environment proceedings no. 145. Baltic Marine Environment Protection Commission, Helsinki

HELCOM (2018a) Water clarity. HELCOM core indicator report. www.helcom.fi/wp-content/uploads/2019/08/Water -clarity-HELCOM-core-indicator-2018.pdf

HELCOM (2018b) Sources and pathways of nutrients to the Baltic Sea. Baltic Sea environment proceedings no. 153. Baltic Marine Environment Protection Commission, Helsinki

* Hellemann D, Tallberg P, Bartl I, Voss M, Hietanen S (2017) Denitrification in an oligotrophic estuary: a delayed sink for riverine nitrate. Mar Ecol Prog Ser 583:63-80

* Hietanen S, Kuparinen J (2008) Seasonal and short-term variation in denitrification and anammox at a coastal station on the Gulf of Finland, Baltic Sea. Hydrobiologia 596: $67-77$

*Huettel M, Gust G (1992) Impact of bioroughness on interfacial solute exchange in permeable sediments. Mar Ecol Prog Ser 89:253-267

*Huettel M, Ziebis W, Forster S (1996) Flow-induced uptake of particulate matter in permeable sediments. Limnol Oceanogr 41:309-322

Jäntti H, Hietanen S (2012) The effects of hypoxia on sediment nitrogen cycling in the Baltic Sea. Ambio 41:161-169

Jäntti H, Stange F, Leskinen E, Hietanen S (2011) Seasonal variation in nitrification and nitrate-reduction pathways in coastal sediments in the Gulf of Finland, Baltic Sea. Aquat Microb Ecol 63:171-181 
Jensen MM, Lam P, Revsbech NP, Nagel B, Gaye B, Jetten MSM, Kuypers MMM (2011) Intensive nitrogen loss over the Omani Shelf due to anammox coupled with dissimilatory nitrite reduction to ammonium. ISME J 5:1660-1670

Joensuu M, Pilditch CA, Harris R, Hietanen S, Pettersson H, Norkko A (2018) Sediment properties, biota, and local habitat structure explain variation in the erodibility of coastal sediments. Limnol Oceanogr 63:173-186

Jørgensen BB, Sørensen J (1985) Seasonal cycles of $\mathrm{O}_{2}, \mathrm{NO}_{3}{ }^{-}$ and $\mathrm{SO}_{4}{ }^{2-}$ reduction in estuarine sediments: the significance of an $\mathrm{NO}_{3}{ }^{-}$reduction maximum in spring. Mar Ecol Prog Ser 24:65-74

Kraft B, Tegetmeyer HE, Sharma R, Klotz MG and others (2014) The environmental controls that govern the end product of bacterial nitrate respiration. Science 345: 676-679

Leppäranta M, Myrberg K (2009) Physical oceanography of the Baltic Sea. Springer-Verlag, Berlin

Marchant HK, Lavik G, Holtappels M, Kuypers MMM (2014) The fate of nitrate in intertidal permeable sediments. PLOS ONE 9:e104517

Middelburg J, Soetaert K (2004) The role of sediments in shelf ecosystem dynamics. Geochim Cosmochim Acta 68: A343

Nielsen LP (1992) Denitrification in sediment determined from nitrogen isotope pairing. FEMS Microbiol Ecol 86: 357-362

Nielsen LP, Glud RN (1996) Denitrification in a coastal sediment measured in situ by the nitrogen isotope pairing technique applied to a benthic flux chamber. Mar Ecol Prog Ser 137:181-186

Nielsen K, Nielsen LP, Rasmussen P (1995) Estuarine nitrogen retention independently estimated by the denitrification rate and mass balance methods: a study of Norsminde Fjord, Denmark. Mar Ecol Prog Ser 119:275-283

Niemi Å (1973) Ecology of phytoplankton in the Tvärminne area, SW coast of Finland. I. Dynamics of hydrography, nutrients, chloporphyll a and phytoplankton. Acta Bot Fennica 100:1-68

Niemistö J, Lund-Hansen LC (2019) Instantaneous effects of sediment resuspension on inorganic and organic benthic nutrient fluxes at a shallow water coastal site in the Gulf of Finland, Baltic Sea. Estuaries Coasts 42:2054-2071

R Core Team (2014) R: a language and environment for statistical computing. R Foundation for Statistical Computing, Vienna

Ramsing N, Gundersen J (2012) Seawater and gases: tabulated physical parameters of interest to people working with microsensors in marine systems. Unisense, Aarhus

Reigstad M, Wassmann P (1996) Importance of advection for pelagic-benthic coupling in north Norwegian fjords. Sarsia 80:245-257

Riebesell U (1989) Comparison of sinking and sedimentation rate measurements in a diatom winter/spring bloom. Mar Ecol Prog Ser 54:109-119

Risgaard-Petersen N, Rysgaard S, Revsbech NP (1995) Combined microdiffusion-hypobromite oxidation method for determining nitrogen-15 isotope in ammonium. Soil Sci Soc Am J 59:1077-1080

Risgaard-Petersen N, Nielsen LP, Rysgaard S, Dalsgaard T, Meyer RL (2003) Application of the isotope pairing tech-

Editorial responsibility: Robinson Fulweiler, Boston, Massachusetts, USA nique in sediments where anammox and denitrification coexist. Limnol Oceanogr Methods 1:63-73

* Rysgaard S, Risgaard Petersen N, Sloth NP, Jensen K, Nielsen LP (1994) Oxygen regulation of nitrification and denitrification in sediments. Limnol Oceanogr 39:1643-1652

* Rysgaard S, Christensen PB, Nielsen LP (1995) Seasonal variation in nitrification and denitrification in estuarine sediment colonized by benthic microalgae and bioturbating infauna. Mar Ecol Prog Ser 126:111-121

Rysgaard S, Glud RN, Risgaard-Petersen N, Dalsgaard T (2004) Denitrification and anammox activity in Arctic marine sediments. Limnol Oceanogr 49:1493-1502

Schlitzer R (2015) Ocean data view. http://odv.awi.de

Schulz HD (2005) Quantification of early diagenesis: dissolved constituents in marine pore water. In: Schulz HD, Zabel M (eds) Marine geochemistry, 2nd edn. Springer, Berlin, p 73-124

* Seeberg-Elverfeldt J, Schlüter M, Feseker T, Kölling M (2005) Rhizon sampling of porewaters near the sedimentwater interface of aquatic systems. Limnol Oceanogr Methods 3:361-371

* Silvennoinen H, Hietanen S, Liikanen A, Stange CF, Russow R, Kuparinen J, Martikainen PJ (2007) Denitrification in the river estuaries of the northern Baltic Sea. Ambio 36: $134-140$

Slater JM, Capone DG (1987) Denitrification in aquifer soil and nearshore marine-sediments influenced by groundwater nitrate. Appl Environ Microbiol 53:1292-1297

Soana E, Naldi M, Bonaglia S, Racchetti E and others (2015) Benthic nitrogen metabolism in a macrophyte meadow (Vallisneria spiralis L.) under increasing sedimentary organic matter loads. Biogeochemistry 124:387-404

* Song GD, Liu SM, Kuypers MMM, Lavik G (2016) Application of the isotope pairing technique in sediments where anammox, denitrification, and dissimilatory nitrate reduction to ammonium coexist. Limnol Oceanogr Methods 14: 801-815

Sørensen J (1984) Seasonal variation and control of oxygen, nitrate, and sulfate respiration in coastal marine sediments. In: Klug MJ, Reddy CA (eds) Current perspectives in microbial ecology. Proceedings of the third international symposium on microbial ecology, 7-12 Aug 1983, East Lansing, MI. American Society for Microbiology, Washington, DC, p 447-453

* Taylor PG, Townsend AR (2010) Stoichiometric control of organic carbon-nitrate relationships from soils to the sea. Nature 464:1178-1181

Tiedje JM (1988) Ecology of denitrification and dissimilatory nitrate reduction to ammonium. In: Zehnder AJB (ed) Environmental microbiology of anaerobes. John Wiley and Sons, New York, NY, p 179-244

*Tuominen L, Heinänen A, Kuparinen J, Nielsen LP (1998) Spatial and temporal variability of denitrification in the sediments of the northern Baltic Proper. Mar Ecol Prog Ser 172:13-24

Van Cappellen P, Wang Y (1995) Metal cycling in sediments: modeling the interplay of reaction and transport. In: Allen HE (ed) Metal contaminated aquatic sediments. Ann Arbor Press, Ann Arbor, MI

Wentworth CK (1922) A scale of grade and class terms for clastic sediments. J Geol 30:377-392

Submitted: May 13, 2019; Accepted: February 6, 2020

Proofs received from author(s): March 2, 2020 